\title{
EDITORIAL
}

\section{In This Issue: The Science, Art, and Policy of Primary Care}

\author{
Robin S. Gotler, MA, Reflections Editor/Editorial Coordinator
}

Ann Fam Med 2009;7:194-195. DOI: 10.1370/afm.1001.

$\mathrm{T}$ his issue highlights the art and science of primary care, the role of policy in "nurtur[ing] and support[ing] the idea of primary care," 1 and the rich insights that develop when these domains intersect.

\section{TESTING AND ERRORS}

As the number of cancer screening tests increases with advances in technology and proliferation of guidelines, what are the costs - in resource and human terms - of the increasing numbers of false-negative test results? Croswell and colleagues studied a large program that screened for cancers of the prostate, lung, colon, and ovary among adults aged 55 to 74 years. ${ }^{2}$ The cumulative rate over 3 years of at least 1 false-positive test was high, 60\% for men and 49\% for women. Clinicians and policy makers need to keep in mind that people, not just cases, undergo tests.

Most research on medical errors addresses systems and clinicians. According to Buetow and colleagues, we must also account for patients' role in errors. This study presents the first taxonomy of patient errors, a 3-level system that includes action errors and mental errors. ${ }^{3}$ As the authors acknowledge, the addition of patients to this field of study is provocative. Is it a sign of respect for patients' ability "to make choices and err, $^{\prime 3}$ or do patient errors imply blame? Share your thoughts in our online discussion.

\section{ETHICS, POLICY, AND PRIMARY CARE}

When patients can no longer make decisions about their medical care, surrogate decision makers become involved. An ethics analysis by Braun et $\mathrm{al}^{4}$ provide new insights into this phenomenon by distinguishing between making decisions for the patient and reporting on the patient's preferences. Clinicians can relieve some of the burden of surrogacy by making this distinction clear.
Bennett and colleagues shed light on the underresearched relationship between health literacy, health disparities, and preventive services. ${ }^{5}$ Using a skillbased assessment method in a nationally representative sample of older adults, they found that health-related print literacy contributes to disparities associated with race/ethnicity and education in self-rated health and utilization of influenza vaccination. Education-related disparities were also associated with utilization of mammography and dental care. ${ }^{5}$

The second in a series of editorials explores the generalist approach and its value for patients, clinicians, health care systems, communities, and beyond. It illustrates the importance of comprehensive, personalized primary care and calls on us to "temper our gullibility in believing that quick-fix, no-pain solutions exist for our complex problems." ${ }^{6}$

\section{RESEARCH METHODS}

Three studies in this issue contribute to the methods of primary care research. Van Ravesteijn et al address somatoform disorders, common and difficult problems for both patients and clinicians. ${ }^{7}$ They evaluate the performance of a self-administered questionnaire for detecting somatoform disorders in a high-risk primary care population and find that it is valid and moderately reliable.

The CHAT is a short, self-administered Case-finding and Help Assessment Tool for lifestyle and mental health assessment. A study in this issue evaluates the additional benefit of asking whether patients would like help with the issues addressed by the tool. It finds that doing so increases specificity and positive predictive value. ${ }^{8}$

In surveys of physician members of practice-based research networks, Kroth and team demonstrate that paper-and-pencil mail surveys still add to newer electronic survey methods in achieving high response rates. ${ }^{9}$ 


\section{THE FUTURE OF PRIMARY CARE}

Many individuals and organizations see the patient-centered medical home $(\mathrm{PCMH})$ as a key to the future of primary care. In this issue, we publish an initial report from the independent evaluation team of the United States' first PCMH National Demonstration Project. ${ }^{10}$ The report offers early lessons from ongoing analyses, which have the potential to inform the many medical home projects underway. The PCMH has been described as possibly "the most profound transformation of the health care system in anyone's memory." 11 This report attempts to place such expectations in the context of the realities that practice redesign entails.

A series of essays by Loxterkamp brings to life another element that is vital to primary care's future: relationships. ${ }^{12-15}$ Relationships should guide us as we conduct research, practice medicine, formulate health policy, and dream of a medical home we can call our own. These essays are as relevant to the science and policy of primary care as they are to its art, because, as an accompanying editorial states, "narrative may help discern the best future for family medicine." 16

We welcome your voice in the discussion of articles at www.AnnFamMed.org.

To read or post commentaries in response to this article, see it online at http://www.annfammed.org/cgi/content/full/7/3/194.

\section{References}

1. Mullen, F. Big Doctoring in America. University of California Press, Berkeley, CA; 2002.

2. Croswell JM, Kramer BS, Kreimer AR, et al. Cumulative incidence of false-positive results in repeated, multimodal cancer screening. Ann Fam Med. 2009;7(3):212-222.
3. Buetow S, Kiata L, Liew T, Kenealy T, Dovey S, Elwyn G. Patient error: a preliminary taxonomy. Ann Fam Med. 2009;7(3):223-231.

4. Braun UK, Naik AD, McCullough LB. Reconceptualizing the experience of surrogate decision making: reports vs genuine decisions. Ann Fam Med. 2009;7(3):249-253.

5. Bennett IM, Chen J, Soroui JS, White S. The contribution of health literacy to disparities in self-rated health status and preventive health behaviors in older adults. Ann Fam Med. 2009;7(3):204-211.

6. Stange KC. The generalist approach. Ann Fam Med. 2009;7(3): 198-203.

7. van Ravesteijn $H$, Wittkampf $K$, Lucassen $P$, et al. Detecting somatoform disorders in primary care with the PHQ-15. Ann Fam Med. 2009;7(3):232-238.

8. Goodyear-Smith F, Arroll B, Coupe N. Asking for help is helpful: validation of a brief lifestyle and mood assessment tool in primary health care. Ann Fam Med. 2009;7(3):239-244.

9. Kroth PJ, McPherson L, Leverence R, et al. Combining Web-based and mail surveys improves response rates: a PBRN study from PRIME Net. Ann Fam Med. 2009;7(3):245-248.

10. Nutting PA, Miller WL, Crabtree BF, Jaen CR, Stewart EE, Stange KC. Initial lessons from the first National Demonstration Project on practice transformation to a patient-centered medical home. Ann Fam Med. 2009;7(3):254-260.

11. Robert Graham Center. The Patient Centered Medical Home. History, Seven Core Features, Evidence and Transformational Change. http:// www.graham-center.org/PreBuilt/PCMH.pdf. Accessed Mar 13, 2009.

12. Loxterkamp D. A change will do you good. Ann Fam Med. 2009; $7(3): 261-263$

13. Loxterkamp D. The dream of home ownership. Ann Fam Med. 2009;7(3):264-266.

14. Loxterkamp D. Doctors' work: eulogy for my vocation. Ann Fam Med. 2009;7(3):267-268.

15. Loxterkamp D. The old duffers' club. Ann Fam Med. 2009;7(3): 269-272.

16. Marnocha M. What truly matters: relationships and primary care. Ann Fam Med. 2009;7(3):196-197. 